\title{
Timing of Vegetation Sampling at Greater Sage-Grouse Nests
}

\author{
Doris Hausleitner, ${ }^{1}$ Kerry P. Reese, ${ }^{2}$ and Anthony D. Apa ${ }^{3}$ \\ Authors are ${ }^{1}$ MS Graduate and ${ }^{2}$ Professor in the Department of Fish and Wildife Resources, University of Idaho, \\ Moscow, ID 83844; and ${ }^{3}$ Sage-Grouse Research Biologist, Colorado Division of Wildlife, Grand Junction, CO 81505.
}

\begin{abstract}
Habitat management guidelines for greater sage-grouse, Centrocercus urophasianus, have been formulated, in part, based on studies of nest site selection. However, these guidelines may not represent conditions when the female initiates nesting because sampling occurs posthatch (> 30 days after nest initiation) to avoid disturbing incubating females. In 2002, we investigated differences in 22 habitat variables at initiation and hatch. Sampling was at 30 randomly selected active nests marked in 2001. There was no significant difference in structural or cover data $(P>0.05)$. Grass height and percent grass cover differed $(P<0.05)$ based on timing of sampling. Grass heights at the nest bowl and at $1 \mathrm{~m}$ from the edge of the nest bowl were 10 and $9 \mathrm{~cm}$ at initiation and 16 and $13 \mathrm{~cm}$ at hatch, respectively. Percent grass cover increased from $4 \%$ to $6 \%$ cover from initiation to hatch. Sampling occurred in a dry year; differences in grass heights and percent cover may be more pronounced in years of normal precipitation. Preliminary results indicated current habitat sampling techniques conducted posthatching adequately described selection of structural components of shrub height, visual obstruction, and percent cover of shrubs, bare ground, litter, and forbs at the nest site at initiation. Data need to be verified for other study areas and under different climatic conditions.
\end{abstract}

\section{Resumen}

Los lineamientos de manejo del hábitat del "Greater sage-grouse" (Centrocercus urophasianus) han sido formulados, en parte, basados en estudios de selección del sitio para anidar. Sin embargo, estos lineamientos, pueden no representar las condiciones cuando las hembras inician el anidamiento, porque el muestreo ocurre después de que el polluelo sale del huevo (> 30 días después de iniciado el anidamiento) para evitar el disturbio de las hembras que están incubando. En el 2002, investigamos las diferencias en 22 variables del hábitat al inicio del anidamiento y ruptura del huevo por el polluelo. El muestro se hizo en 30 nidos activos seleccionados aleatoriamente y marcados en el 2001. No hubo diferencia significativa en los datos de estructura y cobertura $(P>0.05)$. La altura de los zacates y porcentaje de cobertura de zacates difirió $(P<0.05)$ en base a la época de muestreo. Las alturas de los zacates en el nido y a $1 \mathrm{~m}$ del límite de este fueron de 10 y $9 \mathrm{~cm}$ al inicio y 16 y $13 \mathrm{~cm}$ al momento de emerger el polluelo respectivamente. El porcentaje de cobertura de zacates aumentó de $4 \%$ a $6 \%$ del inicia al momento de que el polluelo emergió. El muestreo ocurrió en un año seco, por lo que las diferencias en la altura de los zacates y porcentaje de cobertura pueden ser más pronunciadas en años con precipitación normal. Los resultados preliminares indicaron que las técnicas actuales de muestreo del hábitat, realizadas después de que los polluelos emergen, describieron adecuadamente la selección de los componentes estructurales de la altura del arbusto, la obstrucción visual y el porcentaje de cobertura de arbustos, suelo desnudo, mantillo y hierbas en el sitio de anidamiento al momento de iniciar esta actividad. Los datos necesitan ser verificados para otras áreas de estudio bajo diferentes condiciones climáticas.

Key Words: Centrocercus urophasianus, Colorado, nest site selection, nest initiation

\section{INTRODUCTION}

Microhabitat sampling for nest use and selection studies of ground-nesting sage-steppe (Reynolds 1981), grassland birds (With and Webb 1993), and grouse and quail (Storaas and Wegge 1987; Kilbride et al. 1992; McKee et al. 1998) have typically been done after nesting ceases to avoid disruption of incubation. This practice is also prevalent in habitat studies of

Research was funded by Colorado Division of Wildlife, National Fish and Wildlife Foundation, US Bureau of Land Management, Colowyo Coal Company, L.P. Association, Trapper Mining Company, Moffat County, and Yampa Valley Electric Company.

Correspondence: Dr Kerry Reese, Dept of Fish and Wildlife Resources, University of Idaho, 6th and Line Streets, Moscow, ID 84844. Email: kreese@uidaho.edu

Manuscript received 15 December 2004; manuscript accepted 15 June 2005. greater sage-grouse, Centrocercus urophasianus (Klebenow 1969; Connelly et al. 1991; Gregg et al. 1994; Musil et al. 1994). These measurements do not consider plant growth and/ or senescence and cannot accurately reflect vegetation structure at time of nest site selection (Reese et al. 1987).

The guidelines presented by Connelly et al. (2000) for managing greater sage-grouse nesting cover are based primarily on vegetation data collected posthatch, which may exceed 30 days after nest initiation. Our objective was to measure and compare nest site characteristics at nest initiation to those at the cessation of nesting using the previous year's nest sites. The sampling procedure assumes the previous year's nests adequately describe habitat chosen in the subsequent year and climatic conditions describe typical vegetation growth during the incubation period. 


\section{METHODS}

\section{Study Area}

The study area encompassed 200,000 ha and included Axial Basin and Danforth Hills, in Moffat County, $30 \mathrm{~km}$ south of Craig, Colorado (lat $40^{\circ} 30^{\prime} \mathrm{N}$, long $107^{\circ} 31^{\prime} \mathrm{W}$ ). The 30 nests sampled were distributed over 25,000 ha and 20 pastures. The topography consists of rolling hills ranging in elevation from 1818 to $2388 \mathrm{~m}$. Moffat County is semiarid, with mean annual temperature and precipitation of $6.1^{\circ} \mathrm{C}$ and $43 \mathrm{~cm}$, respectively (WRCC 2001). Precipitation in northwest Colorado from April to June in 2001 and 2002 was 37 and $16 \mathrm{~cm}$, respectively (NOAA 2004). The landscape consists of private, state, and federally owned/administered sagebrush rangeland (Artemisia tridentata spp. wyomingensis Beetle \& Young with Artemisia t. spp. vaseyana (Rydb.) Boivin at higher elevations), pinyon (Pinus edulis Engelm.)-juniper (Juniperus monosperma (Engelm.) Sarg., J. osteosperma (Torr. Little, J. scopulorum Sarg.), mountain shrub communities with Gambel oak (Quercus gambelii Nutt.), serviceberry (Amelanchier Medik. spp.), snowberry (Symphoricarpos oreophilus Gray), and chokecherry (Prunus virginiana L.), Conservation Reserve Program lands, surface coal mines, and agricultural lands of primarily wheat (Triticum aestivum L.) and alfalfa (Medicago sativa L.). The shrub-steppe community is dominated by an overstory of big sagebrush and snowberry. The predominant grasses within this community include western wheatgrass (Pascopyrum smithii (Rydb.) A. Love), Kentucky bluegrass (Poa pratensis L.), Sandberg bluegrass (P. secunda J. Presl.), cheatgrass brome (Bromus tectorum L.), and needle and thread grass (Hesperostipa comata (Trin. \& Rupr.) Barkworth). Dominant forbs include lupine (Lupinus sericeus L.), wild onion (Allium L. spp.), arrowleaf balsamroot (Balsamorhiza sagittata (Pursh) Nutt.), and yarrow (Achillea millefolium L.) (USDA, NRCS 2004 was used as the source for plant scientific nomenclature). Sheep, cattle, and horses are the domestic grazers and mule deer (Odocoileus hemionus), pronghorn (Antilocapra americana), and elk (Cervus elaphus) comprise the wild ungulates.

\section{Capture and Monitoring}

Sixty-six female grouse were captured on 11 leks during April and May 2001. Females were radiomarked with 17-g, necklacemounted transmitters (Samuel and Fuller 1996). Using the loudest signal method (Springer 1979), grouse were located with a 3-element hand-held Yagi antenna attached to a receiver/ scanner. Nest sites were found by monitoring females 2-3 times per week until nest initiation. Monitoring continued until nesting efforts ceased. We recorded exact Universal Transverse Mercator coordinates for nest sites and marked them with metal stakes to facilitate locating them in 2002.

\section{Vegetation Sampling}

We sampled vegetation at nest initiation (18-29 April 2002) and hatch (18 May-4 June 2002) at 30 nest sites randomly chosen from 40 nests active and marked in 2001. Because of logistical constraints, not all nests marked were sampled. Sixteen nests were successful ( $\geq 1$ egg hatched) and 14 were unsuccessful, mimicking the natural success rates and range of habitat variation of grouse nests in the study area (Hausleitner
2003). In addition, 54 nests from 2002 were sampled at the cessation of nesting (17 May-13 June).

Vegetation was sampled within a plot $20 \mathrm{~m}$ in diameter centered on the nest. Four 10-m transects emanating along the cardinal directions from the plot center were used to sample shrub canopy cover by species using line-intercept methods (Canfield 1941). Height of the nest shrub and the nearest shrub within $1 \mathrm{~m}$ of the transect line was measured at 2.5, 5, 7.5, and $10 \mathrm{~m}$ using a meter stick. Grass height was measured using a meter stick and the droop height was recorded for the nearest live grass at the points where the edge of the nest bowl and the transect intersected, and at the 1-m point on each transect, resulting in 4 grass height measurements at the nest bowl and 4 grass height measurements at the $1-\mathrm{m}$ point in the cardinal directions.

Two $40 \times 50 \mathrm{~cm}$ microplots (Nelle et al. 2000) were placed at the intersection point of the transects with one corner on the edge of the nest bowl going north or south along the transect. Subsequent plots were placed with the outermost corner along the 4 transects at $2.5,5$, and $10 \mathrm{~m}$, for a total of 14 microplots at each nest site. Eleven cover classes were delineated (1: $0 \%-$ 2\%, 2: 3\%-9\%, 3: 10\%-19\%, 4: 20\%-29\%, 5: 30\%-39\%, 6: 40\%-49\%, 7: 50\%-59\%, 8: 60\%-69\%, 9: 70\%-79\%, 10: $80 \%-89 \%$, and 11: $90 \%-100 \%)$. Forb, grass, bare ground, and litter cover was estimated in each microplot as class 1 through 11.

Concealment of the nest was measured using a $12 \times 12 \mathrm{~cm}$ cover-board separated into $25,3 \times 3 \mathrm{~cm}$ squares (modified from Jones 1968). The cover-board was placed over the nest bowl and the number of squares $>50 \%$ concealed was recorded from a height of $1.5 \mathrm{~m}$.

\section{Statistical Analysis}

Vegetation variables, other than grass height, were separated into those measured at the nest bowl and those measured in the surrounding area $(2.5,5$, and $10 \mathrm{~m})$. Grass height measurements were separated into those at the nest bowl and at $1 \mathrm{~m}$ from the nest bowl. The midpoints of each cover class estimate from microplots were used to calculate means for the nest plot. Variables were arcsine transformed to meet the assumption of univariate normality. Multivariate normality was assessed through graphical and tabular means; our assessment was that the normality assumption was met. A correlation analysis was performed on the habitat variables to reduce the dimensionality. We used a repeated measures multivariate analysis of variance (MANOVA) to assess differences in the remaining variables due to timing of vegetation sampling. Evaluation of univariate ANOVA and canonical analysis were used to evaluate which variables contributed to overall differences (SAS Institute 2000).

\section{RESULTS}

We measured 22 habitat variables, but 12 were removed from further analysis due to collinearity and dimensionality. A difference was detected in vegetation by time of measurement (Wilk's $\lambda=0.27 ; F=5.32 ; 10,20 \mathrm{df} ; P=0.001$ ) for all the remaining 10 habitat variables. Habitat variables contributing to this difference included grass heights at 0 and $1 \mathrm{~m}$, and average percent grass cover (Table 1). Other habitat variables, 
Table 1. Mean and standard error (SE) for habitat variables included in MANOVA at initiation and hatch for 30 greater sage-grouse nests from 2001 measured in 2002 in Moffat County, Colorado.

\begin{tabular}{lccccc}
\hline & \multicolumn{2}{c}{ Initiation } & & \multicolumn{2}{c}{ Hatch } \\
\cline { 2 - 3 } \cline { 5 - 6 } Variable & Mean & SE & & Mean & SE \\
\hline Concealment, no. squares & 15.4 & 0.05 & & 13.6 & 1.4 \\
Sagebrush cover, ${ }^{1} \%$ & 29.9 & 2.6 & & 29.9 & 2.8 \\
Nest shrub height, cm & 81.9 & 3.5 & & 82.8 & 3.7 \\
Shrub height, cm & 51.9 & 3.1 & & 52.7 & 3.3 \\
Grass height at 0 m, ${ }^{2} \mathrm{~cm}$ & 10.0 & 0.6 & & 15.6 & 1.1 \\
Grass height at $1 \mathrm{~m}^{2}{ }^{2} \mathrm{~cm}$ & 8.5 & 0.4 & & 13.3 & 0.7 \\
Forb cover, ${ }^{1} \%$ & 3.8 & 0.7 & & 5.1 & 0.9 \\
Grass cover, ${ }^{1,3} \%$ & 3.5 & 0.4 & & 5.5 & 0.8 \\
Bare ground, ${ }^{1} \%$ & 15.9 & 2.5 & & 14.0 & 2.3 \\
Litter cover, ${ }^{1} \%$ & 80.5 & 2.4 & & 82.1 & 2.5 \\
\hline
\end{tabular}

${ }^{1}$ Arcsine transformed for MANOVA, untransformed mean, and SE are reported

${ }^{2}$ Significantly different at $\alpha<0.001$.

${ }^{3}$ Significantly different at $\alpha<0.05$.

especially those associated with sagebrush height and cover, did not differ from initiation to hatch. At nest initiation, females selected shrubs with a mean height of $82 \mathrm{~cm}$ within a stand of shrubs with average height of $52 \mathrm{~cm}$ and sagebrush canopy cover of $30 \%$ (Table 1). Vegetation characteristics sampled at 54 nests posthatch in 2002 were not statistically different (Wilk's $\lambda=0.72 ; F=1.37 ; 18,63 \mathrm{df} ; P=0.178$ ) from the 2001 nest sites sampled at hatch in $2002(n=30)$.

\section{DISCUSSION}

We assessed characteristics of vegetation at nest initiation, given that these should best represent structure sought by females throughout incubation. Structural components did not change between assessment times (initiation and the cessation of nesting), and corresponded to those recommended in the literature (Connelly et al. 2000). Sampling at nest cessation adequately described habitat characteristics at nest selection, with the exception of grass height and cover. Grass height and cover were important in modeling nest site selection and success in the study area (Hausleitner 2003).

Grass cover increased by only $2 \%$, whereas height increased by $<6 \mathrm{~cm}$, which may be biologically inconsequential. However, these changes in grass cover and grass heights between initiation and hatch would be more profound in years of normal precipitation. To illustrate this, posthatch mean grass heights at 0 and $1 \mathrm{~m}$ were 15.5 and $19.6 \mathrm{~cm}$ at all nest sites in 2001 and 12.5 and $13.6 \mathrm{~cm}$ in 2002 (Hausleitner 2003), respectively. The difference between years can be attributed to drier conditions in 2002.

The sampling procedure and its application are limited by the assumption that nest sites from 2001 represented those selected in 2002. Similarity in vegetation characteristics at 2001 and 2002 nest sites sampled in the same year posthatch, and nest fidelity, lend credibility to this assumption (Hausleitner 2003). In addition, the dry conditions in 2002 may not adequately represent vegetation growth in years of normal precipitation.

\section{MANAGEMENT IMPLICATIONS}

We provided a nonintrusive technique to sampling greater sagegrouse nest sites that simulated the structural characteristics at nest initiation. Our results suggest some structural variables (visual obstruction; sagebrush cover; nest shrub height; shrub height; and forb, bare ground, grass, and litter cover) may be measured at any time during incubation to describe adequately nest sites at initiation. Managers must be cautious in measuring grass cover and height at any time during incubation. To best describe nest site selection, we recommend these variables be assessed at nest initiation. These results represent a single year of sampling and need to be verified under different climatic conditions and geographical locations within the greater sagegrouse range.

\section{ACKNOWLEDGMENTS}

The authors thank the North American Grouse Partnership and Monarch and Associates for logistical support. We thank K. B. Olree, B. A. Palmer, H. D. Antonio, Z. M. Miller, S. M. Quinlivan, M. P. Schenk, C. P. Collins, E. M. Trimble, E. S. Rock, and T. D. Abraham for assistance in fieldwork, and R. W. Hoffman, K. A. Logan, P. A. Talcott, R. G. Wright, R. K. Steinhorst, and E. O. Garton for comments and suggestions on the manuscript.

\section{LITERATURE CITED}

Canfield, R. H. 1941. Application of the line interception method in sampling range vegetation. Journal of Forestry 39:388-394.

Connelly, J. W., M. A. Schroeder, A. R. Sands, and C. E. Braun. 2000. Guidelines to manage sage grouse populations and their habitats. Wildlife Society Bulletin 28:967-985.

Connelly, J. W., W. L. Wakkinen, A. D. Apa, and K. P. Reese. 1991. Sage grouse use of nest sites in southeastern Idaho. Journal of Wildlife Management 55:521-524.

Gregg, M. A., J. A. Crawford, M. S. Drut, and A. K. Delong. 1994. Vegetational cover and predation of sage grouse nests in Oregon. Journal of Wildlife Management 58:162-166.

HAUSLeITNER, D. 2003. Population dynamics, habitat use and movements of greater sage-grouse in Moffat County, Colorado [MS thesis]. Moscow, ID: University of Idaho.

JoNES, R. E. 1968. A board to measure cover used by prairie grouse. Journal of Wildlife Management 32:28-31.

Kilbride, K. M., J. A. Crawford, K. L. Blakely, and B. A. Williams. 1992. Habitat use by breeding female California quail in western Oregon. Journal of Wildlife Management 56:85-90.

KLEBENow, D. A. 1969. Sage grouse nesting and brood habitat in Idaho. Journal of Wildlife Management 33:649-662.

McKee, G., M. R. Ryan, and L. M. Mechlin. 1998. Predicting prairie-chicken nest success from vegetation and landscape characteristics. Journal of Wildlife Management 62:314-321.

Musil, D. D., K. P. Reese, And J. W. Connelly. 1994. Nesting and summer habitat use by translocated sage grouse (Centrocercus urophasianus) in central Idaho. Great Basin Naturalist 54:228-233.

Nelle, P. J., K. P. Reese, And J. W. Connelly. 2000. The long-term effect of fire on sage grouse nesting and brood-rearing habitat on the Upper Snake River Plain. Journal of Range Management 53:586-591.

NOAA. 2004. Climate prediction center. Available at: http://www.cpc.ncep.noaa. gov. Accessed 11 April 2005.

ReEse, K. P., J. A. Kadlec, and L. M. Smith. 1987. Characteristics of islands selected 
by nesting Canada geese, Branta canadensis. Canadian Field Naturalist 101:539-542.

REYNoLDS, T. D. 1981. Nesting of the sage thrasher, sage sparrow and Brewer's sparrow in southeastern Idaho. Condor 83:61-64.

Samuel, M. D., and M. R. Fuller. 1996. Wildlife radiotelemetry. In: T. A. Bookhout [ED.]. Research and management techniques for wildlife and habitats. 5th ed., rev. Bethesda, MD: The Wildlife Society. p 370-418.

SAS InSTITUTE INC. 2000. SAS/STAT users guide, version 8.2. Cary, NC: SAS Institute Inc.

Springer, J. T. 1979. Some sources of bias and sampling error in radio triangulation. Journal of Wildlife Management 43:926-935.
StoraAs, T., and P. WegGe. 1987. Nesting habitats and nest predation in sympatric populations of capercaillie and black grouse. Journal of Wildlife Management 51:167-172.

USDA, NRCS. 2004. The PLANTS database, Version 3.5. Available at: http:// plants.usda.gov. Accessed 10 April 2005.

WRCC. 2001. Western Regional Climate Center: Colorado Climate Summaries. Available at: http://www.wrcc.dri.edu/. Accessed 10 April 2005.

With, K. A., and D. R. WebB. 1993. Microclimate of ground nests: the relative importance of radiative cover and breaks for three grassland species. Condor 95:401-413. 